\title{
Potensi Sampah Organik Sebagai Bahan Baku Pembuatan Briket Bio Arang
}

\author{
Wetri Febrina \\ Program Studi Teknik Industri, Sekolah Tinggi Teknologi Dumai \\ Jl. Utama Karya Bukit Batrem II \\ Email: wetri.febrina@gmail.com
}

\begin{abstract}
ABSTRAK
Krisis energi memicu eksplorasi besar-besaran terhadap berbagai sumber energi alternatif jika bahan bakunya berasal dari limbah dan sampah. Upaya peningkatan nilai jual dan kemanfaatan dari sampah dapat dilakukan melalui program pengolahan sampah organik menjadi briket bioarang. Briket bioarang berasal dari bahan baku tempurung kelapa dan kulit jengkol sebagai. Kadar air briket arang yang dihasilkan berkisar antara 5,781\%-6,1\%. Hasil ini telah memenuhi persyaratan kualitas briket arang SNI 8\%. Jika dilihat dari variasi perbandingan briket Tempurung Kelapa 60\% dan Serbuk kulit jengkol 30\% dan Tempurung Kelapa 30\% dan Serbuk Kulit jengkol 60\%, briket yang dibuat dari bahan baku dengan campuran kulit jengkol yang banyak akan menyebabkan kandungan air yang tinggi. Sedangkan briket yang bahan bakunya tempurung kelapa yang lebih banyak menyebabkan rendahnya kadar air yang dihasilkan. Nilai rata-rata kadar abu yang dihasilkan berkisar antara $2,55 \%-7,51 \%$. Nilai kadar abu dari briket yang dihasilkan ini telah memenuhi kualitas standar SNI 8\%. Nilai kadar abu terendah sebesar $2,55 \%$ terdapat pada $90 \%$ arang kulit jengkol sedangkan nilai tertinggi yaitu $7,51 \%$ terdapat pada $90 \%$ arang Tempurung Kelapa. Hasil penelitian disimpulkan bahwa briket bioarang dari campuran kulit jengkol dan tempurung kelapa layak dikembangkan untuk industri rumah tangga karena kualitas arang yang dihasilkan sudah memenuhi standar SNI.
\end{abstract}

Kata kunci: Briket bioarang, Tempurung kelapa, Kulit jengkol, Kalor pembakaran.

\begin{abstract}
Energy crisis sparked a massive exploration of alternative energy sources if the raw material comes from waste and garbage. The efforts increased value and benefit from the garbage can be done through the course of the processing of organic waste into briquettes bioarang. Briquettes bioarang derived from raw coconut shell and skin in Curry as. Moisture content of charcoal briquettes produced ranged from 5,781\%-6.1\%. These results have met the requirements of the quality charcoal briquettes SNI 8\%. If viewed from a coconut shell briquettes comparison variation of $60 \%$ and $30 \%$ of the skin in Curry Powder and coconut shell Skin Powder 30\% and 60\% in Curry, briquettes made from raw skin in Curry blends with which many will cause the moisture content height. While the briquettes that are raw material coconut shell more cause low levels of produced water. The average value of the resulting grey levels ranged from $2.55 \%-7.51 \%$. The value of the levels of ash from the resulting briquettes has complied with standard quality LEVEL of $8 \%$. The lowest levels of grey value of

UNITEX Vol 11 No.1 Januari - Juni 2018 p-ISSN 2089-3957 | e-ISSN 2580-2585
\end{abstract}


$2.55 \%$ found in $90 \%$ of skin in Curry charcoal while the highest value i.e. $7.51 \%$ found on $90 \%$ charcoal coconut shell. Results of the study it was concluded that briquettes bioarang of a mixture of skin in Curry and coconut shell worth developed for household industry due to the quality of the resulting charcoal is already meet the standards of SNI.

Keywords: Bioarang, coconut shell briquettes, Heat, burning Skin in Curry.

\section{Pendahuluan}

Beberapa negara di dunia sudah mulai menggunakan sumber energi terbaru berupa briket dari berbagai jenis sampah dan sudah mulai dikembangkan. Gambaran potensi sampah tersebut dapat dijadikan sebagai inovasi bagi pengolah sampah. Ide dan pola fikir yang demikian didukung dengan partisipasi masyarakat yang menunjang tidak menutup kemungkinan dan seharusnya roda perputaran ekonomi bisa lebih bagus lagi sehingga perekonomian masyarakat menjadi lebih baik. Menurut Lailatul fitriya dkk (2010) program pengolahan sampah menjadi briket adalah upaya peningkatan nilai jual dan kemanfaatan dari sampah. Program ini juga bertujuan mengatasi permasalahan sampah yang kita hadapi. Briket dari sampah ini juga bias menjadi solusi krisis energi. Penggunaan briket relatif bertahan lama. Briket sampah yang dapat digunakan hingga 5 jam untuk memasak. Briket yang berdiameter 10 centimeter yang terbuat dari sampah ini mampu menghasilkan energi panas hingga 500 derajat Celsius selama 5 jam. Seperti yang dijelaskan sebelumnya, bahwa dalam penggunaannya, briket ini tidak menimbulkan asap. Namun briket ini memiliki kelemahan yakni membutuhkan waktu 20 hingga 30 menit hingga bisa menciptakan energi panas yang cukup tinggi untuk memasak.

Briket ini dibuat dari sampah organik seperti daun kering yang dibakar diatas tungku hingga menjadi arang. Sampah organik yang teksturnya tidak keras, seperti daun-daunan menghasilkan briket sarang tawon. Sedangkan jenis sampah yang keras seperti batok kelapa, ranting pohon, kulit durian menghasilkan briket yang sama seperti arang yang dapat menghasilkan bara api. Kualitas briket tergantung pada proses pembuatannya. Kepadatan dan kadar air dari briket mempengaruhi kualitasnya. Jika lem yang digunakan kurang maka briket mudah hancur sehingga menyulitkan penggunaannya ketika dibakar. Menurut Esmar budi (2011) Telah dikaji proses pembentukan dan pemanfaatan arang tempurung kelapa (cocos nucifera) sebagai bahan dasar briket bahan bakar. Proses pembentukan briket arang tempurung mencangkup persiapan bahan tempurung kelapa, proses pirolisis, pengilingan, pencetakan hingga pengeringan. Pemanfaatan briket arang tempurung kelapa dalam proses pemanasan menunjukan kemampuannya sebagai bahan bakar pengganti yang bersih.

Pemanfaatan arang tempurung kelapa sebagai bahan bakar rumah tangga telah lama dilakukan masyarakat asia dikarenakan ketersediaan bahan mentah yang berlimpah serta mudah dalam persiapan dan pembentukannya. Dengan tingkat

UNITEX Vol 11 No.1 Januari - Juni 2018 p-ISSN 2089-3957 | e-ISSN 2580-2585 
difusi termal yang lebih besar dari jenis kayu lain maka tempurung kelapa sesuai untuk dimanfaatkan dalam kegiatan industri dan rumah tangga (memasak). Kemasan terbaru dari arang tempurung kelapa adalah dalam bentuk briket yang lebih praktis, bersih dan tidak berasap. Tulisan ini membahas hasil kajian pemanfaatan briket arang tempurung sebagai bahan bakar pengganti dalam kegiatan memasak. Menurut I W Ambara antara dkk (2016) Adanya peningkatan konsumsi pemakaian energi dan berkurangnya cadangan minyak bumi dan batu bara yang merupakan bahan bakar yang berasal dari fosil, maka dilakukan penelitian untuk menemukan cadangan sumber energi biomassa yang dikembangkan melalui batok kelapa muda karena ketersediannya cukup melimpah, batok kelapa muda. Untuk mengolah batok kelapa muda ini menjadi energi alternatif mengalami kendala, antara lain kadar moisture dan asapnya tinggi, nilai kalor rendah, sertakadar karbon masih rendah. Maka untuk mengatasi hal ini, digunakan teknologi pirolisis karena teknologi pirolisis ini menawarkan sejumlah keunggulan terutama pirolisis fluidisasi bed. Pirolisis adalah dekomposisi kimia bahan organic melalui proses pemanasan tanpa atau sedikit oksigen atau reagen lainnya, di mana material mentah akan mengalami pemecahan struktur kimia menjadi fase gas.

Selama ini ada beberapa penelitian tentang pirolisis yang telah dilakukan untuk pembuatan briket salah satunya dengan sistem pirolisis/proses karbonisasi yang dilakukan dapat meningkatkan kandungan karbon dan nilai kalor briket dari tongkol jagung. Pada proses pirolisis ini, biomassa dipanaskan pada temperatur $350^{\circ} \mathrm{C}$ sampai $500^{\circ} \mathrm{C}$ dan dengan sedikit atau tanpa adanya udara maupun oksigen, Pirolisis umumnya dilakukan pada rentang waktu 30 menit sampai 2 jam. Hasil yang didapat dari proses pirolisis adalah sebuah padatan (arang) yang menyimpan $60 \%-70 \%$ energi yang berasal dari biomassa tersebut. Adanya gas inert $\left(N_{2}\right)$ mampu meningkatkan nilai kalor basah maupun kering dari briket bioarang. waktu penahanan (holding time) memberikan efek penyempurnaan pirolisis. Proses dekomposisi kimia dengan menggunakan pemanasan tanpa kehadiran oksigen disebut proses pirolisis atau bisa disebut thermolisis, di mana pada proses ini menghasilkan produk berupa bahanbakar padat yaitu karbon. Seperti diketahui bahwa karbon merupakan salah satu penyusun sumber energi terbesar di dalam briket bioarang. Gas Pirolisis memiliki banyak $\mathrm{CO}_{2}, \mathrm{CO}, \mathrm{H}_{2}, \mathrm{C}_{1-5}$, Hidrokarbon sebagai gas yang mudah terbakar.

\section{Metode Penelitian}

Penelitian ini adalah penelitian eksperimen yang dilakukan selama 2 bulan, bertempat di Sekolah tinggi Teknologi Dumai. Alat-alat yang digunakan adalah seperangkat alat pencetak briket, drum pembakaran sebagai alat pembakaran, neraca analitik, Bom alorimeter sebagai alat untuk mengukur nilai kalor, cawan porselin sebagai wadah contoh uji, krus tang, lumpang dan alu, oven, ayakan tepung,

UNITEX Vol 11 No.1 Januari - Juni 2018 p-ISSN 2089-3957 | e-ISSN 2580-2585 
kompor, spatula, furnace, desikator untuk mendinginkan contoh uji, dan peralatan gelas lainnya. Sampel yang digunakan dalam penelitian ini adalah limbah tempurung kelapa dan kulit jengkol yang terdapat di Kota Dumai. Bahan penunjang lain dalam penelitian ini berupa air, tepung tapioka (kanji).

Tahapan dalam pelaksanaan penelitian ini adalah :

1. Persiapan

2. Karbonasi Tempurung Kelapa dan kulit jengkol

3. Pembuatan Briket Arang Tempurung Kelapa dan kulit jengkol

4. Karakterisasi Briket Arang Tempurung Kelapa dan kulit jengkol

Tahap persiapan yaitu pengumpulan dan pengeringan sampel. Sampel limbah tempurung kelapa dan kulit jengkol diambil di Kota Dumai. Kemudian limbah tersebut dikeringkan dibawah sinar matahari sampai semua kering. Untuk proses karbonasi yang pertama dilakukan yaitu limbah tempurung kelapa dipotong kecilkecil agar mudah proses pembakarannya. Sedangkan kulit jengkol langsung diletakkan pada drum pembakaran. Untuk memudahkan pembakaran digunakan bahan bakar umpan yaitu minyak tanah yang diletakkan ke bagian tengah drum. Setelah bahan bakar umpan dinyalakan dan api menyala stabil, drum ditutup dengan penutup yang dilengkapi dengan cerobong sebagai tempat keluarnya asap. Pembakaran dilakukan dengan drum yang sama secara bergantian. Tempurung kelapa adalah sampel yang pertama kali dibakar. Pembakaran tempurung kelapa membutuhkan waktu $\mathrm{n}$ jam untuk menjadi arang. Sedangkan serbuk kayu gegaji proses pembakarannya membutuhkan waktu hingga $n$ jam. Setelah semua bahan baku menjadi arang, arang tersebut dikeluarkan dan dipisahkan dengan yang menjadi abu. Kemudian didinginkan. Arang yang sudah dingin dilakukan penggilingan hingga halus dan dilakukan pengayakan hingga menjadi bubuk arang.

Pembuatan briket arang diawali dengan proses karbonasi/pengarangan kemudian dilanjutkan dengan penggilinggan arang dan pengayakan. Arang yang sudah halus dicampur dengan perekat tapioca sehingga terbentuk adonan siap cetak. Pencetakan briket dilakukan dari masing-masing sampel yaitu 80\% KJ:0\% TK, 64\% KJ:16\% TK, 48\% KJ:32\% TK, 32\% KJ:48\% TK, 16\% KJ:64\% TK, 0\% KJ:80\% TK. Untuk mencetak briket digunakan alat cetak sederhana berupa pipa paralon. Briket yang sudah dicetak kemudian dikeringkan dengan tujuan agar briket yang dihasilkan mudah dibakar dan siap pakai. Pengeringan dilakukan dalam oven selama $\mathrm{n}$ jam dengan suhu $\mathrm{n}$ C.

Contoh uji ditimbang dalam porselin yang telah diketahui berat tetapnya. Dimasukkan ke dalam oven pada suhu $104-110^{\circ} \mathrm{C}$ selama 1 jam sampai beratnya konstan. Kemudian didinginkan ke dalam desikator selama 5 menit dan timbang. Kadar air dihitung dengan menggunakan persamaan :

$\mathrm{KA}=\frac{x_{1}+x_{2}}{x_{1}} \times 100$

Keterangan : KA= Kadar Air (\%)

$\mathrm{X} 1$ = berat contoh sebelum dikeringkan (gram)

$\mathrm{X} 2$ = berat contoh setelah dikeringkan (gram)

UNITEX Vol 11 No.1 Januari - Juni 2018 p-ISSN 2089-3957 | e-ISSN 2580-2585 


\section{Kadar Abu (Percentage Ash Content-PAC-ASTM)}

Untuk menentukan kadar abu ditimbang $1 \mathrm{~g}$ briket kemudian dimasukkan ke dalam furnace hingga suhu $550^{\circ} \mathrm{C}$ selama $\mathrm{n}$ jam kemudian didinginkan dan ditimbang berat sampel. Kadar abu dapat ditentukan dengan rumus :

$$
\mathrm{PAC}=\mathrm{D} / \mathrm{B} \times 100
$$

dimana $\mathrm{D}$ adalah berat abu dan $\mathrm{B}$ adalah berat sampel.

\section{Dekomposisi Senyawa Volatil (Percentage Volatile Matter-PVM-ASTM)}

Untuk menentukan senyawa yang menguap pertama-tama ditimbang briket sebanyak 1g. Kemudian dimasukkan ke dalam oven hingga beratnya telah konstan. Briket difurnace hingga suhu $550^{\circ} \mathrm{C}$ selama 10 menit. Setelah itu didinginkan dan ditimbang. Hasilnya ditentukan dengan menggunakan rumus : $\mathrm{PVM}=\frac{B-C}{B} \times 100$

Dimana B adalah berat sampel sesudah di oven dan $\mathrm{C}$ adalah berat sampel setelah difurnace .

\section{Kadar Karbon terikat(Percentage Fixed Carbon-PFC- ASTM)}

Kadar karbon terikat dapat dihitung dengan mengurangi penjumlahan dari dekomposisi senyawa volatil dan kadar abu dari 100 (Emerhi, 2011).

Karbon Terikat $(\%)=100-($ dekomposisi senyawa volatil + kadar abu $)$

\section{Kerapatan(Heating Value-HV)}

Kerapatan pada umumnya dinyatakan dalam perbandingan berat dan volume, yaitu dengan cara menimbang dan mengukur volume dalam keadaan kering udara. Kerapatan briket dapat dihitung dengan menggunakan persamaan :

$\mathrm{K}=\frac{G}{V}$

Keterangan :

$\mathrm{K}=$ Kerapatan $(\mathrm{g} / \mathrm{cm} 3)$

$\mathrm{G}=$ Bobot briket $(\mathrm{g})$

$\mathrm{V}=$ Volume (cm3) (Wijayanti, 2009).

\section{Nilai Kalor}

Pengujian nilai kalor dilakukan menggunakan alat oksigen bom kalorimeter. Cara pengujian nilai kalor mengikuti pedoman ASTM D-2015 (Anonim, 1979) dengan prosedur pengujian sebagai berikut:

1. Tahap persiapan alat.

a) Mengambil sebagian sampel briket arang dan menimbangnya dengan berat \pm 1 gram, kemudian cuplikan briket arang diletakkan di mangkok pembakaran dan ditimbang sebagai berat $\mathrm{m} 1$.

b) Memasang kawat nikel sepanjang $10 \mathrm{~cm}$ pada elektrode dan disentuhkan pada cuplikan tanpa menyinggung mangkok pembakaran.

c) Mengisi silinder bom dengan air aquades setinggi $1 \mathrm{~mm}$ dan memasang kepala bom pada silinder bom dan mengisi oksigen murni 99,5\%, sehingga tekanannya mencapai $30 \mathrm{~atm}$. 
d) Mengisi panci silinder dengan air sebanyak 2 liter dan dimasukkan dalam mantel silinder.

e) Memasukkan bom silinder ke dalam panci silinder dan memasang 2 chop beserta kabelnya untuk aliran listrik AC 23 volt yang terangkai pada tutup mantel silinder.

f) Menutup mantel silinder sehingga pengaduk dapat berputar secara bebas dan thermometer (ketelitian $0,2^{\circ} \mathrm{C}$ ) menghadap ke depan pengukur selain itu juga mempersiapkan stopwatch untuk mengukur waktu.

g) Mempersiapkan tabel pengukuran.

2. Tahap pengukuran

a) Menjalankan pengaduk selama 5 menit, dimana selama waktu tersebut tiap satu menit dicatat perubahan suhunya, untuk pengukuran nilai a, r1, dan ta.

b) Pada saat waktu a tercapai, saklar (23 volt) dihidupkan sesaat selama 2 detik, selanjutnya mulai mencatat t $30 "+\mathrm{a}, \mathrm{t} 45 ”+\mathrm{a}, \mathrm{t} 75 ”+\mathrm{a}, \mathrm{t} 90 ”+\mathrm{a}, \mathrm{t} 105 ”$ + a (perubahan suhu setiap 15 detik). Pengukuran suhu pada selang waktu tersebut untuk tujuan penentuan nilai $60 \%$ dari dt (total pembakaran) dan selanjutnya nilai $60 \%$ dt tersebut tercapai pada titik suhu yang mana pada selang waktu t30" + a hingga t105" + a sebagai nilai tb dan waktu b ditentukan dari hasil interpolasi tb.

c) Selanjutnya setelah titik t105" + a, pengukuran suhu dilakukan setiap 1 menit. Jika titik suhu tidak terjadi perubahan lagi, maka setelah 5 menit dari titik tersebut proses pengukuran dihentikan dengan cara menghentikan putaran pengaduk. Titik suhu adalah tc dan titik waktunya adalah nilai c.

3. Tahap pembongkaran.

a) Melepas sabuk pemutar dan membuka mantel silinder serta mengeluarkan silinder bom dari dalam panci silinder.

b) Membebaskan tekanan gas yang ada dalam silinder bom dan membuka silinder bom dengan memutar dan mengangkat kepala bom kalorimeter.

c) Mengambil mangkok pembakaran dan menimbangnya sebagai berat $\mathrm{m} 2$.

d) Mencuci dengan aquades semua permukaan baja yang ada dalam silinder bom dan kepala bom bagian dalam, kemudian air ditampung dalam gelas piala $50 \mathrm{ml}$. Air hasil tampungan kemudian ditetesi dengan larutan indikator methyl orange 3 tetes (warna cairan akan berubah menjadi merah muda) dan dititrasi dengan larutan $\mathrm{Na} 2 \mathrm{CO} 3$ (3,84 gram/liter) yang terdapat pada buret $(50 \mathrm{ml})$ sampai warna merah muda berubah menjadi merah pucat/bening. Jumlah $\mathrm{ml}$ yang tercapai setara dengan jumlah kalor $(1 \mathrm{ml} \sim$ 1 kalori) sebagai koreksi asam (e1).

e) Mengambil kawat pembakar yang tidak ikut terbakar dan meletakkan pada skala pengukuran kalor yang telah dikonversi dari panjang kawat $(1 \mathrm{~cm} \sim 1$ kalori), sebagai koreksi dari panjang sisa kawat yang tidak terbakar (e2). 
f) Dengan langkah yang sama dilakukan pembakaran asam benzoat untuk peneraan alat bom kalorimeter nilai w.

Setelah dilakukan pengujian terhadap nilai kalor, kemudian dibuat perhitungan nilai kalor dengan menggunakan standar ASTM D-2015 (Anonim, 1979) yang perhitungannya sebagai berikut :

$\mathrm{t}=\mathrm{tc}-\mathrm{ta}-\mathrm{r} 1(\mathrm{~b}-\mathrm{a})-\mathrm{r} 2(\mathrm{c}-\mathrm{b})$

$\mathrm{W}=\frac{6381+e 1+e 2}{t}$

$\mathrm{Hg}=\frac{t w-e 1-e 2}{t}$.

Keterangan :

a : waktu pembakaran (menit)

b : waktu yang diperlukan untuk mencapai $60 \%$ pembakaran total, diperoleh dengan interpolasi (menit)

c : waktu yang ditunjuk saat tidak ada perubahan suhu setelah proses pembakaran (menit)

$\mathrm{t}:$ koreksi kenaikan suhu $\left({ }^{\circ} \mathrm{C}\right)$

ta : temperatur pada saat pembakaran $\left({ }^{\circ} \mathrm{C}\right)$

tc : temperatur pada saat mencapai waktu c $\left({ }^{\circ} \mathrm{C}\right)$

$\mathrm{r} 1$ : temperatur rata - rata setiap menit sebelum terjadi pembakaran $\left({ }^{\circ} \mathrm{C} / \mathrm{menit}\right)$

$\mathrm{r} 2$ : temperatur rata - rata setiap menit setelah terjadi pembakaran $\left({ }^{\circ} \mathrm{C} /\right.$ menit $)$

e1 : standar larutan alkali yang digunakan pada titrasi asam (ml)

e2 : sisa panjang kawat setelah pembakaran $(\mathrm{cm})$

$\mathrm{m}$ : mass, selisih berat sampel uji sebelum dan sesudah pengujian (gram)

$\mathrm{w}$ : ekuivalen energi kalorimeter dari pembakaran asam benzoat $\left(\mathrm{kal} /{ }^{\circ} \mathrm{C}\right)$

$\mathrm{Hg}$ : nilai kalor (kal/gram)

\section{Hasil dan Pembahasan}

\section{Hasil Karakterisasi Briket Arang}

Pengujian karakteristik briket meliputi kadar air, kadar abu, kadar zat menguap, dan nilai kalor. Pengujian dilakukan di laboratorium PT. Ciliandra Perkasa Divisi-Biodisel Pelintung.

Tabel 1. Data hasil karakteristik briket tempurung kelapa dan kulit jengkol

\begin{tabular}{|c|l|c|c|c|c|}
\hline No & \multicolumn{1}{|c|}{ Nama Bahan } & Moist (\%) & $\begin{array}{c}\text { Ash } \\
\text { Content } \\
\mathbf{( \% )}\end{array}$ & $\begin{array}{c}\text { Kadar Zat } \\
\text { Menguap } \\
\mathbf{( \% )}\end{array}$ & $\begin{array}{c}\text { Kalori } \\
\text { Cal/g }\end{array}$ \\
\hline 1 & $30 \% \mathrm{KJ}+60 \% \mathrm{TK}$ & 5.798 & 5,54 & 1.7 & 5493.6 \\
\hline 2 & $40 \% \mathrm{KJ}+50 \% \mathrm{TK}$ & 5.819 & 4,78 & 2.28 & 5035.5 \\
\hline 3 & $50 \% \mathrm{KJ}+40 \% \mathrm{TK}$ & 5.831 & 4,34 & 2.86 & 4877.4 \\
\hline 4 & $60 \% \mathrm{KJ}+30 \% \mathrm{TK}$ & 5.965 & 3,09 & 3.44 & 4519.3 \\
\hline 5 & $90 \% \mathrm{TK}$ & 5.781 & 7,51 & 1.12 & 5651.7 \\
\hline
\end{tabular}

UNITEX Vol 11 No.1 Januari - Juni 2018 p-ISSN 2089-3957 | e-ISSN 2580-2585 


\begin{tabular}{|l|l|l|l|l|l|}
6 & $90 \% \mathrm{KJ}$ & 6.1 & 2,55 & 4.02 & 4061.2 \\
\hline
\end{tabular}

\section{Pembahasan Karakterisasi Briket Arang}

Kadar air briket arang yang dihasilkan berkisar antara 5,781\%-6,1\%. Hasil ini telah memenuhi persyaratan kualitas briket arang SNI 8\%. Secara lengkap kadar air briket ditunjukkan pada Gambar 1.

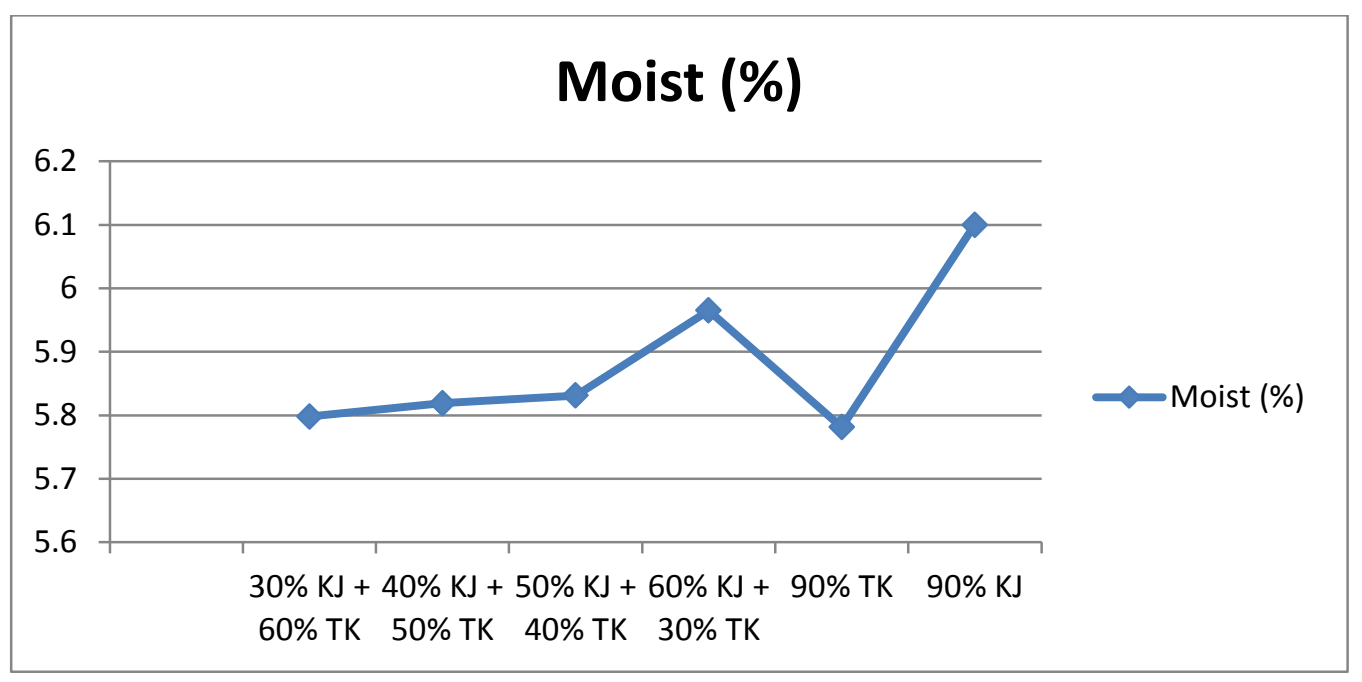

Gambar 1. Grafik kadar air dalam briket

Dari grafik pada Gambar 1 dapat dilihat bahwa kadar air terendah terdapat pada perlakuan komposisi arang Tempurung kelapa (90\%) yaitu 5,781\%. Sementara kadar air tertinggi terdapat pada briket arang kulit jengkol (90\%) yaitu 6,1\%. Kandungan air yang tinggi pada briket juga akan menyulitkan penyalaan briket dan mengurangi temperatur pembakaran (Mislani \& Anugrah 2010). Jika dilihat dari variasi perbandingan briket Tempurung Kelapa 60\% dan Serbuk kulit jengkol 30\% dan Tempurung Kelapa 30\% dan Serbuk Kulit jengkol 60\%, briket yang dibuat dari bahan baku dengan campuran kulit jengkol yang banyak akan menyebabkan kandungan air yang tinggi. Sedangkan briket yang bahan bakunya tempurung kelapa yang lebih banyak menyebabkan rendahnya kadar air yang dihasilkan. Briket arang mempunyai sifat higrokopis yang tinggi sehingga perhitungan kadar air bertujuan untuk mengetahui sifat higrokopis briket arang hasil penelitian. Pengujian kadar air dilakukan setelah briket yang sudah jadi dikeringkan dalam oven selama 2 hari dengan suhu $600 \mathrm{C}$.

\section{Kadar Abu}

Abu merupakan bahan sisa dari pembakaran yang sudah tidak memiliki nilai kalor atau tidak memiliki unsur karbon lagi. Salah satu unsur penyusun abu adalah silika. Pengaruh kadar abu terhadap kualitas briket arang kurang baik, terutama terhadap nilai kalor yang dihasilkan. Kandungan kadar abu yang tinggi dapat 
menurunkan nilai kalor briket arang sehingga akan menurunkan kualitas briket arang (Triono, 2006). Nilai rata-rata kadar abu dapat dilihat pada Gambar 2.

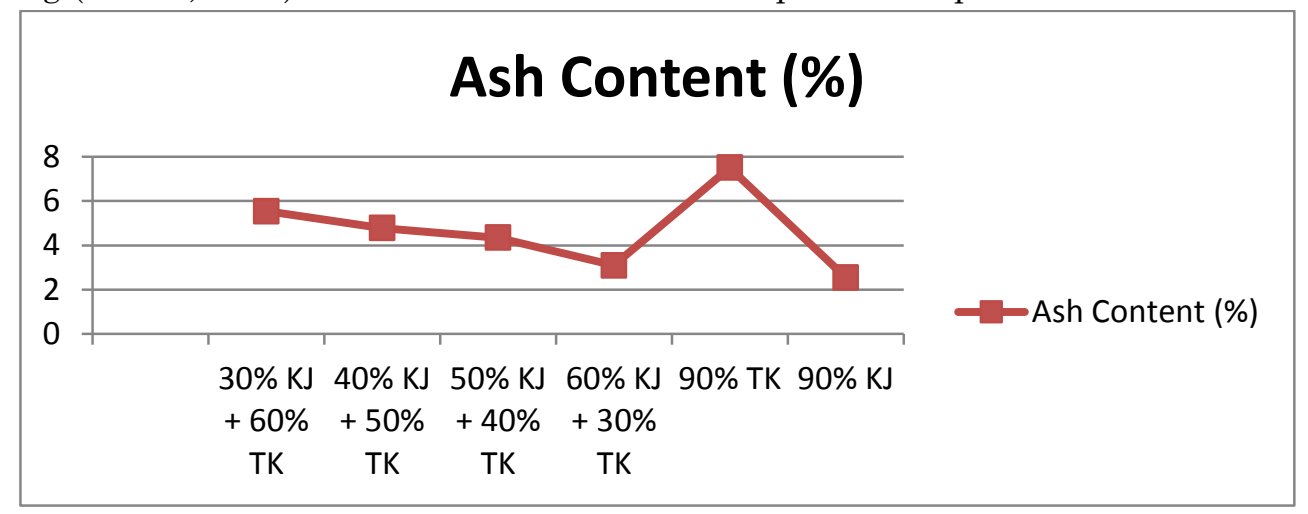

Gambar 2. Grafik kadar abu dalam briket

Nilai rata-rata kadar abu yang dihasilkan berkisar antara 2,55\%-7,51\%. Nilai kadar abu dari briket yang dihasilkan ini telah memenuhi kualitas standar SNI 8\%. Nilai kadar abu terendah sebesar 2,55\% terdapat pada 90\% arang kulit jengkol sedangkan nilai tertinggi yaitu 7,51\% terdapat pada 90\% arang Tempurung Kelapa. Menurut Hendra dan Winarni (2003) dalam Hendra (2007) menyatakan bahwa faktor jenis bahan baku sangat berpengaruh terhadap tinggi rendahnya kadar abu briket arang yang dihasilkan. Cangkang kelapa sawit seperti halnya tempurung kelapa memiliki kandungan silika lebih tinggi dibandingkan dengan serbuk gergajian (Sundari, 2009).

\section{Kadar Zat Menguap}

Kadar zat menguap adalah zat (volatile matter) yang dapat menguap sebagai dekomposisi senyawa-senyawa yang masih terdapat di dalam arang selain air. Kandungan rata-rata dekomposisi senyawa volatil pada briket A, B, C, D dan E adalah 49,296\%. Tinggi rendahnya kadar zat menguap pada briket disebabkan oleh kesempurnaan proses karbonasi dan juga dipengaruhi oleh waktu dan suhu pada 24 proses pengarangan. Semakin besar suhu dan waktu pengarangan maka semakin banyak zat menguap yang terbuang sehingga pada saat penguian kadar zat mengguap akan diperoleh kadar zat menguap yang rendah (Triono, 2006).

Kandungan kadar zat menguap yang tinggi di dalam briket arang akan menyebabkan asap yang lebih banyak pada saat briket dinyalakan. Kandungan asap yang tinggi disebabkan oleh adanya reaksi antar karbon monoksida (CO) dengan turunan alkohol (Hendra dan Pari, 2000 dalam Hendra, 2007). Tinggi rendahnya kadar zat menguap briket arang yang dihasilkan dipengaruhi oleh jenis bahan baku, sehingga perbedaan jenis bahan baku berpengaruh nyata terhadap kadar zat menguap briket arang. Semakin banyak kandungan senyawa volatil pada briket maka briket tersebut akan semakin mudah untuk terbakar dan menyala (Syamsul 2004 dalam Sinurat 2011). Dekomposisi senyawa volatil dalam bahan bakar 
berfungsi untuk menstabilkan nyala dan percepatan pembakaran arang (Sinurat, 2011).

\section{Nilai Kalor}

Nilai kalor sangat menentukan kualitas briket yang dihasilkan. Semakin tinggi nilai kalornya maka semakin tinggi juga kualitas briket yang dihasilkan. Nilai kalor yang didapatkan dari masing-masing briket dapat dilihat pada Gambar 3.

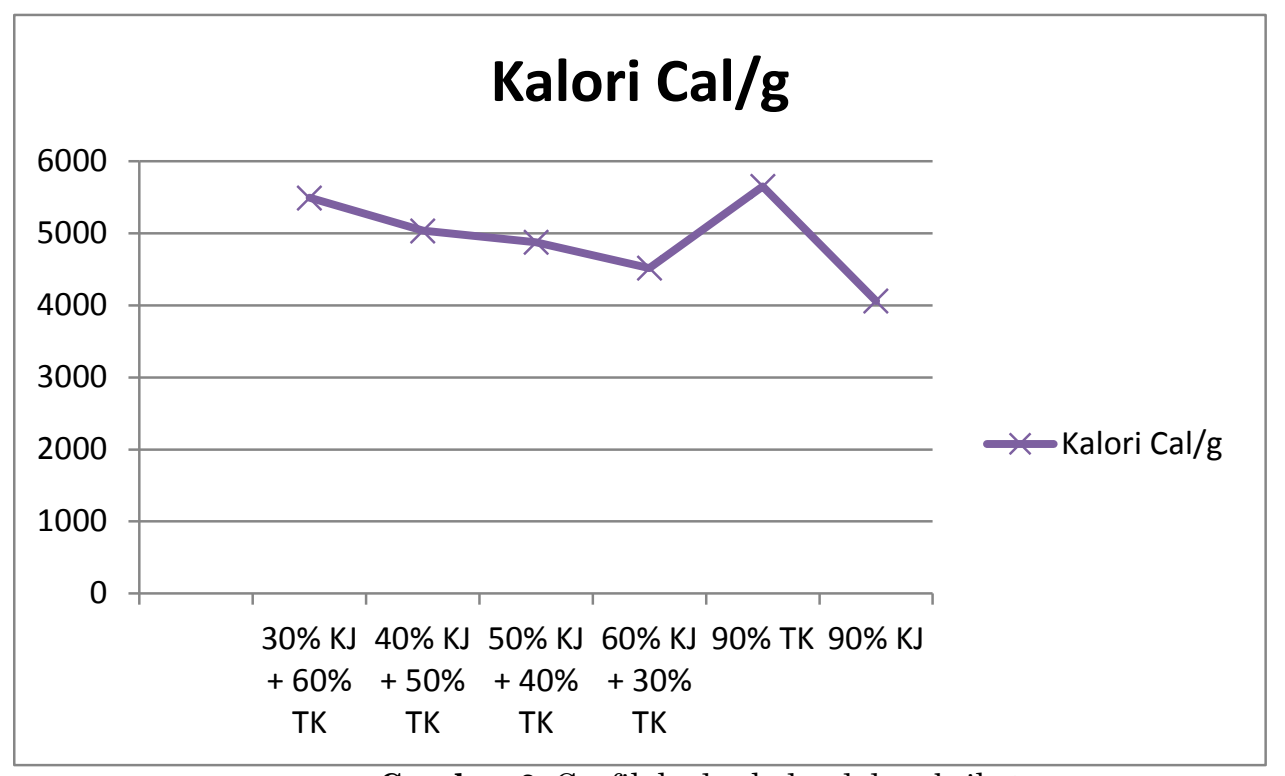

Gambar 3. Grafik kadar kalor dalam briket

Berdasarkan Gambar 3 nilai kalor berkisar antara 4061,2 cal/g - 5651,7 cal/g. Nilai kalor tersebut telah memenuhi standar SNI (5000 cal/g). Nilai kalor tertinggi terdapat pada $90 \%$ arang Tempurung kelapa yaitu 5651,7 cal/g sedangkan nilai kalor terendah terdapat pada $90 \%$ arang kulit jengkol. Jika dilihat dari campuran komposisi briket maka campuran (60:30)\% dan (50:40)\% arang Tempurung kelapa : kulit jengkol nilai kalornya lebih tinggi dibandingkan dengan (30:60)\% dan (40:50)\% arang Tempurung kelapa: kulit jengkol. Tetapi campuran komposisi briket campuran (60:30)\% Tempurung kelapa : kulit jengkol tidak akan mampu menandingi nilai kalor dari 100\% arang tempurung kelapa, sedangkan campuran (30:60)\% Tempurung kelapa : kulit jengkol nilai kalor yang dihasilkan lebih tinggi dari 90\% kulit jengkol. Tinggi rendahnya nilai kalor dipengaruhi oleh kadar abu, kadar air dan kadar karbon terikat pada briket. Menurut Nurhayati (1974) dalam Triono (2006) dinyatakan bahwa tinggi rendahnya nilai kalor dipengaruhi oleh kadar air dan kadar abu briket arang. Semakin tinggi kadar air dan kadar abu briket arang akan menurunkan nilai kalor briket arang yang dihasilkan. Penelitian ini membuktikan bahwa briket yang memiliki kadar air yang rendah akan menghasilkan nilai kalor yang tinggi. Hasil penelitian ini sama dengan hasil penelitian Triono (2006) bahwa jika kadar air rendah maka akan dihasilkan nilai kalor yang tinggi atau sebaliknya.

UNITEX Vol 11 No.1 Januari - Juni 2018 | p-ISSN 2089-3957 | e-ISSN 2580-2585 
Berdasarkan grafik gambar 4.4 nilai kalor berkisar antara 4061,2 cal/g $5651,7 \mathrm{cal} / \mathrm{g}$. Nilai kalor tersebut telah memenuhi standar SNI (5000 cal/g). Nilai kalor tertinggi terdapat pada $90 \%$ arang Tempurung kelapa yaitu 5651,7 cal/g sedangkan nilai kalor terendah terdapat pada $90 \%$ arang kulit jengkol. Jika dilihat dari campuran komposisi briket maka campuran (60:30)\% dan (50:40)\% arang Tempurung kelapa : kulit jengkol nilai kalornya lebih tinggi dibandingkan dengan (30:60)\% dan (40:50)\% arang Tempurung kelapa : kulit jengkol. Tetapi campuran komposisi briket campuran (60:30)\% Tempurung kelapa : kulit jengkol tidak akan mampu menandingi nilai kalor dari $100 \%$ arang tempurung kelapa, sedangkan campuran (30:60)\% Tempurung kelapa : kulit jengkol nilai kalor yang dihasilkan lebih tinggi dari 90\% kulit jengkol. Tinggi rendahnya nilai kalor dipengaruhi oleh kadar abu, kadar air dan kadar karbon terikat pada briket. Menurut Nurhayati (1974) dalam Triono (2006) dinyatakan bahwa tinggi rendahnya nilai kalor dipengaruhi oleh kadar air dan kadar abu briket arang. Semakin tinggi kadar air dan kadar abu briket arang akan menurunkan nilai kalor briket arang yang dihasilkan. Penelitian ini membuktikan bahwa briket yang memiliki kadar air yang rendah akan menghasilkan nilai kalor yang tinggi. Hasil penelitian ini sama dengan hasil penelitian Triono (2006) bahwa jika kadar air rendah maka akan dihasilkan nilai kalor yang tinggi atau sebaliknya.

\section{Simpulan}

Dari penelitian yang telah dilakukan bisa diambil kesimpulan bahwa briket bioarang dari campuran kulit jengkol dan tempurung kelapa ini memiliki potensi dan layak dikembangkan karena kualitas arang yang dihasilkan sudah memenuhi standar SNI, yaitu kadar air briket arang yang dihasilkan berkisar antara 5,781\%$6,1 \%$ (SNI 8\%). Nilai rata-rata kadar abu yang dihasilkan berkisar antara 2,55\% 7,51\% (SNI 8\%). Nilai kalor berkisar antara 4061,2 cal/g - 5651,7 cal/g (nilai kalor tersebut telah memenuhi standar SNI sebesar $5000 \mathrm{cal} / \mathrm{g}$ ). 